\title{
A NATIONAL VOICE FOR NATURALISTS
}

The Canadian Audubon Society, by hosting a conference of Affiliations in Winnipeg on May 16, 17, 18, has taken the initiative in exploring ways of setting up the machinery to deal with environmental problems on a national scale. In his opening remarks the chairman, Ian Tate of the CAS, insisted that the rights and purposes of local and provincial organizations of naturalists be maintained but emphasized the need of a national voice for those interested in preserving a quality environment in Canada.

One of the keynote speakers, Dr. Ted Mosqquin, editor of The Canadian Field-Naturalists, felt that naturalists could no longer justify communicating mainly among themselves. He expressed the need for a national publication which would have a base broad enough to enable naturalists to communicate with the general public. (His conservative estimate of the potential number of readers of such an organ was between thirty and fifty thousand). $\mathrm{He}$ outlined the roles of a national newsletter, a series of nature books, a youth journal and scientific publications with environmental and ecological emphasis. Dr. Mosquin intimated that while the existing naturalist journals (The Blue Jay, The Canadian Field-Naturalist, The Canadian Audubon, etc.) have elements of what he envisioned for national publications, no one of them satisfied all the necessary criteria.

Mr. Gerry McKeating, of the Federation of Ontario Naturalists (FON), outlined recent developments in his organization and attributed the rapid growth of the past few years to active involvement at the grass roots level.

Discussion arising from the presentation by Dr. Timothy Meyers of the Biology Department of the University of Alberta led to the conclusion that the existing structure of the CAS would not allow it to assume the position of a national federation unless existing by-law changes occurred. At this point Dr. Meyers stressed the need for immediate action on the part of all concerned naturalists.

The keynote speakers prepared for the deliberations of a committee which in turn presented a number of recommendations. It was proposed that there be regional representation and direct membership. Twelve regions were agreed upon, these to comprise the ten provinces, the Yukon and the North West Territories. Regional federations such as the Saskatchewan Natural History Society would each appoint one director to the Board of Directors. Twelve directors would be elected by the members of regional organizations and twelve would be elected by members of the national organizations. The executive committee would include a president, three vice-presidents (one from each main region of Canada), a secretary, a treasurer, and three members at large. The function of the Board of Directors would be that of policy maker. The central office, manned by an executive director and staff, would conceivably be the centre of activity. A field director would work as a public relations and liaison officer. Membership would be open to all Canadian Naturalists and would entitle a member to receive the national publication as well as the use of the resource centre. It was recommended that the name of a national union of naturalists be Canadian Nature Federation with its official publication to be called Nature Canada.

These recommendations from the Winnipeg conference were made to the Canadian Audubon Society executive with proposals for setting definite deadlines for guiding future action.

The events of May 16, 17, 18 in Winnipeg are important; the first steps have been taken to fill the need for a national voice for naturalists. Watch the SNHS newsletter for more information concerning specific plans for the formation of a national society. Be prepared to discuss the matter both formally and informally at the annual summer meeting at Waskesiu.-Gordon Silversides, President, SNHS, Moose Jaw. 